\title{
THE AVOIDANCE OF POSTOPERATIVE HYPOXAEMIA: AN ASSESSMENT OF THREE TECHNIQUES FOR USE DURING ANAESTHESIA
}

\author{
H. B. FAIRLEY, M.B., B.S., F.F.A.R.C.S., J. H. KERR, M.A., M.B., B.CHIR., F.R.c.P.(C), \\ A. K. LAWS, B.SC., M.B., B.S., F.F.A.R.C.S., \\ AND G. R. SELIERY, M.D., DIP.ANAES., F.R.C.P. (C) ${ }^{*}$
}

Postoperative hYPoXAema has been shown to occur frequently, ${ }^{1-3}$ and various aetiological factors have been suggested. ${ }^{4}$ The present studies were designed to examine the merits of three possible prophylactic manoeuvres to be applied during anaesthesia: (1) intermittent hyperinflation of the lungs; (2) replacement of preoperative fluid deficit and the use of an "artificial nose"; (3) inspired gases containing nebulized water particles.

\section{Methods}

All patients studied were clinically normal, from the cardiopulmonary standpoint, and were undergoing orthopaedic or other surgery to the periphery. Each manoeuvre was studied by dividing a number of patients into control and "treatment" groups, using a table of random numbers. The means and ranges of the ages of the patients and of the lengths of the operative procedures are shown in Table I.

TABLE I

Means and Ranges of Ages and of Operative Durations for All Patients Studied

\begin{tabular}{|c|c|c|c|c|c|c|}
\hline \multirow[b]{2}{*}{ Study } & \multirow[b]{2}{*}{ Ventilation } & \multirow[b]{2}{*}{ Group } & \multicolumn{2}{|c|}{ Age (years) } & \multicolumn{2}{|c|}{ Duration (minutes) } \\
\hline & & & $\mathrm{m}$ & range & $\mathrm{m}$ & range \\
\hline $\begin{array}{l}\text { Intermittent } \\
\text { hyperinflation }\end{array}$ & spontaneous & $\begin{array}{l}\text { control } \\
\text { treatment }\end{array}$ & $\begin{array}{l}48.5 \\
43.7\end{array}$ & $\begin{array}{l}19-74 \\
19-68\end{array}$ & $\begin{array}{l}103 \\
106\end{array}$ & $\begin{array}{l}44-160 \\
55-215\end{array}$ \\
\hline $\begin{array}{l}\text { Artificial nose } \\
\text { and hydration }\end{array}$ & $\begin{array}{l}\text { spontaneous } \\
\text { I.P.P. }\end{array}$ & $\begin{array}{l}\text { control } \\
\text { treatment } \\
\text { control } \\
\text { treatment }\end{array}$ & $\begin{array}{l}39.4 \\
43.1 \\
32.2 \\
39.5\end{array}$ & $\begin{array}{l}14-69 \\
19-67 \\
18-62 \\
29-60\end{array}$ & $\begin{array}{r}92 \\
93 \\
124 \\
166\end{array}$ & $\begin{array}{r}30-163 \\
45-205 \\
52-205 \\
105-250\end{array}$ \\
\hline Nebulizer & spontaneous & $\begin{array}{l}\text { control } \\
\text { treatment }\end{array}$ & $\begin{array}{l}37.0 \\
36.7\end{array}$ & $\begin{array}{l}18-59 \\
19-64\end{array}$ & $\begin{array}{l}76 \\
64\end{array}$ & $\begin{array}{l}50-114 \\
42-113\end{array}$ \\
\hline
\end{tabular}

All patients breathed room air postoperatively. Arterial blood samples were taken anaerobically, at 15 and 60 minutes, and immediately immersed in ice. Arterial oxygen and carbon dioxide tensions were determined using Radiometer and Severinghaus electrodes respectively, both at $38^{\circ} \mathrm{C}$. The values so obtained were adjusted to the patient's temperature, using the Severinghaus nomogram. ${ }^{5}$ The oxygen electrode was calibrated with gases of known composition and with

- Department of Anaesthesia, University of Toronto. 
tonometerized blood. From these calibrations, blood-gas differences were calculated each day and a correction was applied from the factor so determined. This varied from 1.02 to 1.05 . The accuracy of replicate arterial oxygen tensions determined in this laboratory is shown by a coefficient of variation of 0.5 per cent, for twenty samples tonometerized at $89 \mathrm{~mm}$. $\mathrm{Hg} \mathrm{Po}_{2}$, with a blood-gas correction factor of 1.04 .

Occasional difficulties arose in collecting samples at exactly 15 and 60 minutes. Consequently, all values were plotted as a frequency distribution with respect to time. All distributions were positively skewed and, consequently, values for samples collected after twenty-five minutes and seventy-six minutes, respectively, were excluded.

\section{Study Number 1}

Intermittent hyperinflations. Twenty patients were premedicated with a narcotic and atropine or hyoscine, induced with sodium thiopentone and succinylcholine, intubated, and permitted to breathe nitrous oxide, oxygen, and halothane spontaneously. The lungs of those in the "treatment" group were manually inflated to a volume three times their tidal volume (predicted from the Radford nomogram $^{6}$ at a frequency of $14 / \mathrm{min}$.), and held in inflation to a count of five. This was repeated ten times every ten minutes.

\section{Study Number 2}

Rehydration and "artificial nose." Forty patients were premedicated and anaesthetized as in Study Number 1. Those in the "treatment" group received intravenous fluid to a volume calculated on the basis of $125 \mathrm{ml}$. for each hour between the last oral intake and the end of the surgical procedure. Blood loss was also replaced. In addition, an "artificial nose" endotracheal tube and the anaesthesia circuit.

In a further twenty patients, premedication and anaesthesia were as before, except that d-tubocurarine was also given and the patients received intermittent positive pressure ventilation. The "treatment" group was rehydrated as before and ventilated through an "artificial nose."

\section{Study Number 3}

Inspired air containing nebulized water. In twenty patients, arterial blood samples were drawn before premedication with meperidine ( $0.66 \mathrm{mg} . / \mathrm{lb}$. body weight). Atropine was given intravenously at induction in this study, as a means of avoiding any possibility of subcutaneously administered atropine producing an overriding effect ${ }^{8}$ in both control and "treatment" groups. Anaesthesia was induced with sodium thiopentone and succinylcholine. The patients were then intubated and permitted to breathe nitrous oxide, oxygen, and halothane spontaneously, through a circuit designed to avoid rebreathing. Those in the "treatment" group had nebulized water particles added to the inspired gases, close to the patient, from a Puritan nebulizer activated from an auxiliary gas source flowing at $10 \mathrm{~L} . / \mathrm{min}$. The total flow of gases was adjusted to $20 \mathrm{~L} . / \mathrm{min}$. in both control and "treatment" groups. 


\section{Results}

A summary of the statistical analyses is shown in Tables II-IV. The preoperative values (from the twenty patients in Study Number 3) varied with age according to the regression formula:

$$
\mathrm{Pa}_{\mathrm{O}_{2}}(\mathrm{~mm} . \mathrm{Hg})=101.4-0.52(\text { age })
$$

(95\% conf. limits: $\mathrm{Pa}_{\mathrm{O}_{2}}$ at mean age 37 is $82.2 \pm 15.2 \mathrm{~mm} . \mathrm{Hg}$ ).

TABLE II

Statistical Summary of Results from Study Number 1 (No Statistical Difference)

\begin{tabular}{|c|c|c|c|c|c|c|c|}
\hline \multirow{2}{*}{$\begin{array}{l}\text { Intermittent } \\
\text { hyperinflations }\end{array}$} & \multirow[b]{2}{*}{$\mathrm{N}$} & \multicolumn{3}{|c|}{$\begin{array}{c}\mathrm{Pa}_{2} 15 \mathrm{~min} . \text { postoperatively } \\
(\mathrm{mm} . \mathrm{Hg})\end{array}$} & \multicolumn{3}{|c|}{$\begin{array}{c}\mathrm{Pa}_{2} 60 \mathrm{~min} . \text { postoperatively } \\
(\mathrm{mm} . \mathrm{Hg})\end{array}$} \\
\hline & & $\mathrm{m}$ & 5 & $t$ & $\mathrm{~m}$ & $\mathbf{s}$ & $t$ \\
\hline Control & 9 & 72.5 & 7.6 & $\begin{array}{l}0.02 \\
\text { with } \\
17 \text { d.f. }\end{array}$ & 71.6 & 9.3 & $\begin{array}{l}0.49 \\
\text { with } \\
17 \text { d.f. }\end{array}$ \\
\hline Treatment & 10 & 72.4 & 13.1 & & 76.4 & 28.9 & \\
\hline
\end{tabular}

TABLE III

Statistical Summary of Results from Study Number 2 (No Statistical Difference)

\begin{tabular}{|c|c|c|c|c|c|c|c|c|}
\hline \multirow{2}{*}{$\begin{array}{l}\text { Artificial nose } \\
\text { and hydration }\end{array}$} & \multirow[b]{2}{*}{$\mathrm{N}$} & \multicolumn{3}{|c|}{$\begin{array}{c}\mathrm{PaO}_{2} 15 \text { min. postoperatively } \\
(\mathrm{mm} . \mathrm{Hg})\end{array}$} & \multirow[b]{2}{*}{$\mathrm{N}$} & \multicolumn{3}{|c|}{$\begin{array}{c}\mathrm{Pa}_{2} 60 \text { min. postoperatively } \\
(\mathrm{mm} . \mathrm{Hg})\end{array}$} \\
\hline & & $\mathrm{m}$ & $\mathrm{s}$ & $\mathrm{t}$ & & $\mathrm{m}$ & $\mathrm{s}$ & $\mathrm{t}$ \\
\hline \multicolumn{9}{|l|}{ Spontaneous } \\
\hline control & 18 & 72.8 & 9.3 & \multirow[t]{2}{*}{$\begin{array}{l}0.53 \\
\text { with } \\
35 \text { d.f. }\end{array}$} & 20 & 76.5 & 13.5 & \multirow[t]{2}{*}{$\begin{array}{l}0.18 \\
\text { with } \\
37 \text { d.f. }\end{array}$} \\
\hline treatment & 19 & 74.9 & 14.0 & & 19 & 75.9 & 5.3 & \\
\hline \multicolumn{9}{|l|}{ I.P.P.V. } \\
\hline treatment & 8 & 68.6 & 11.6 & $\begin{array}{l}1.27 \\
\text { with } \\
16 \text { d.f. }\end{array}$ & 10 & 71.7 & 8.5 & $\begin{array}{l}0.70 \\
\text { with } \\
17 \text { d.f. }\end{array}$ \\
\hline
\end{tabular}

TABLE IV

Statistical Summary of Results from Study Number 3 (No Statistical Difference)

\begin{tabular}{|c|c|c|c|c|c|c|c|}
\hline \multirow[b]{2}{*}{ Nebulizer } & \multirow[b]{2}{*}{$\mathbf{N}$} & \multicolumn{3}{|c|}{$\Delta \mathrm{Pa}_{2}(\mathrm{~mm} . \mathrm{Hg})^{*}$} & \multicolumn{3}{|c|}{$\Delta \mathrm{Pa}_{\mathrm{O}_{2}}(\mathrm{~mm} . \mathrm{Hg}) \dagger$} \\
\hline & & $\mathrm{m}$ & $\mathrm{s}_{\mathrm{m}}^{2}$ & $\mathrm{t}$ & $\mathrm{m}$ & $s_{m}^{2}$ & $\mathrm{t}$ \\
\hline Control & 10 & 13.2 & 3.2 & $\begin{array}{l}0.22 \\
\text { with } \\
18 \text { d.f. }\end{array}$ & 5.1 & 6.0 & $\begin{array}{l}1.65 \\
\text { with } \\
18 \mathrm{~d} . \mathrm{f} .\end{array}$ \\
\hline Treatment & 10 & 12.6 & 4.7 & & 10.7 & 5.5 & \\
\hline
\end{tabular}

*Preoperative $\mathrm{Pa}_{2}-\mathrm{Pa}_{2} 15$ minutes postoperatively.

†Preoperative $\mathrm{PaO}_{2}-\mathrm{PaO}_{2} 60$ minutes postoperatively. 
The postoperative oxygen tensions in the same patients were significantly lower (Table IV) $(p<0.001)$. The values from all spontaneously breathing patients in the other control groups also suggest a depression of arterial oxygen tension at 15 and at 60 minutes postoperatively. The relevant regressions are:

$15 \mathrm{~min}$.

$$
\mathrm{Pa}_{\mathrm{O}_{2}}(\mathrm{~mm} . \mathrm{Hg})=81-0.25(\text { age })
$$

(95\% conf. limits: $\mathrm{Pa}_{\mathrm{O}_{2}}$ at mean age 41 is $71 \pm 16.7 \mathrm{~mm} . \mathrm{Hg}$ ).

$60 \mathrm{~min}$.

$$
\mathrm{Pa}_{\mathrm{O}_{2}}(\mathrm{~mm} . \mathrm{Hg})=89.5-0.36(\text { age })
$$

( $95 \%$ conf. limits: $\mathrm{Pa}_{\mathrm{O}_{2}}$ at mean age 41 is $74.7 \pm 20.9 \mathrm{~mm} . \mathrm{Hg}$ ).

None of the prophylactic measures studied showed any statistically significant improvement in the "treatment" groups compared with the control group. The results are plotted in Figures 1-9.

In Studies Number 1 and 2, group means were calculated and compared by $t$-test. In Study Number 3, the 15-minute and 60-minute postoperative value for each patient was compared with that obtained preoperatively. This enabled a comparison of the mean paired differences by $t$-test. In addition, correlation coefficients were calculated for $\mathrm{Pa}_{\mathrm{O}_{2}}$ and $\mathrm{Pa}_{\mathrm{CO}_{2}}$. The results were as follows:

Spontaneously breathing controls

$15 \mathrm{~min}$.

$$
r=-0.11
$$

$60 \mathrm{~min}$.

$$
r=-0.44(p<0.01) \text {. }
$$

Twenty patients following controlled ventilation

$15 \mathrm{~min}$.

$$
r=-0.52(p<0.05)
$$

$60 \mathrm{~min}$.

$$
r=-0.39 \text {. }
$$

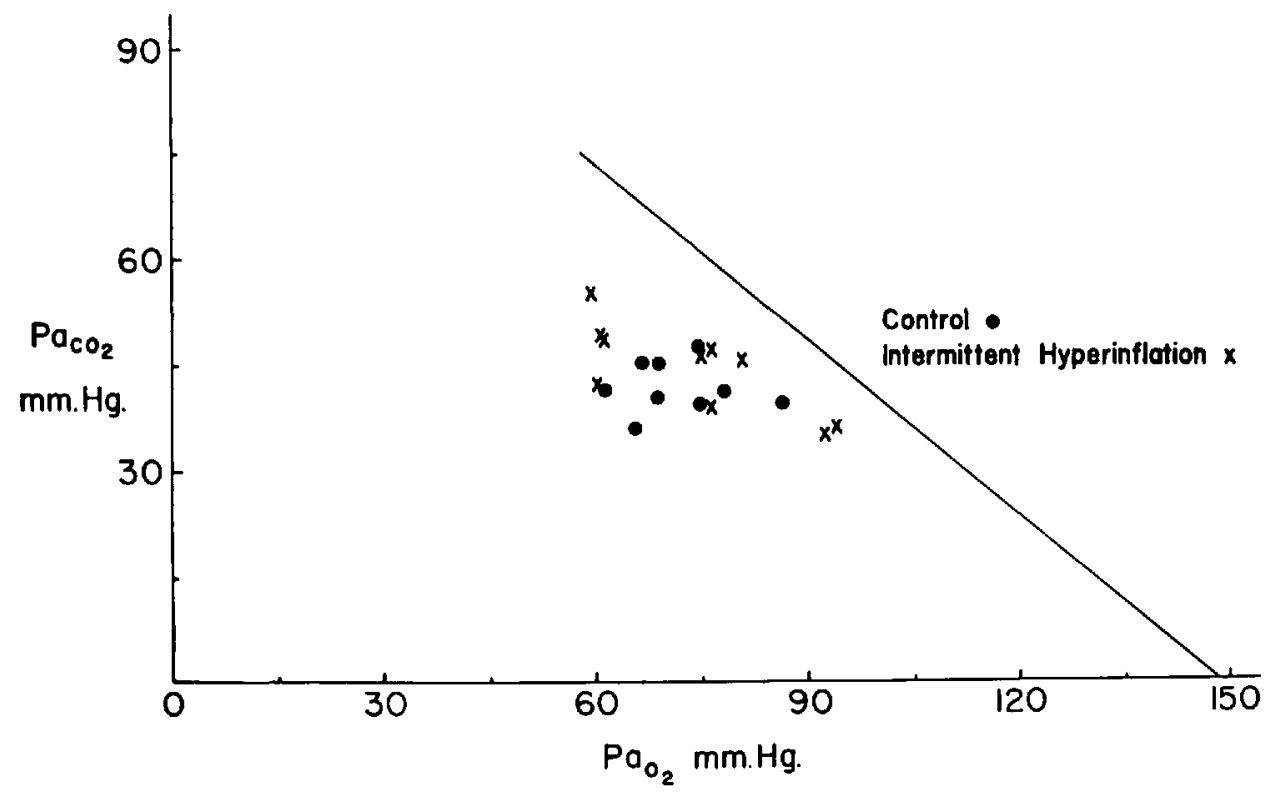

Figure 1. Study Number 1, 15 minutes postoperatively. 


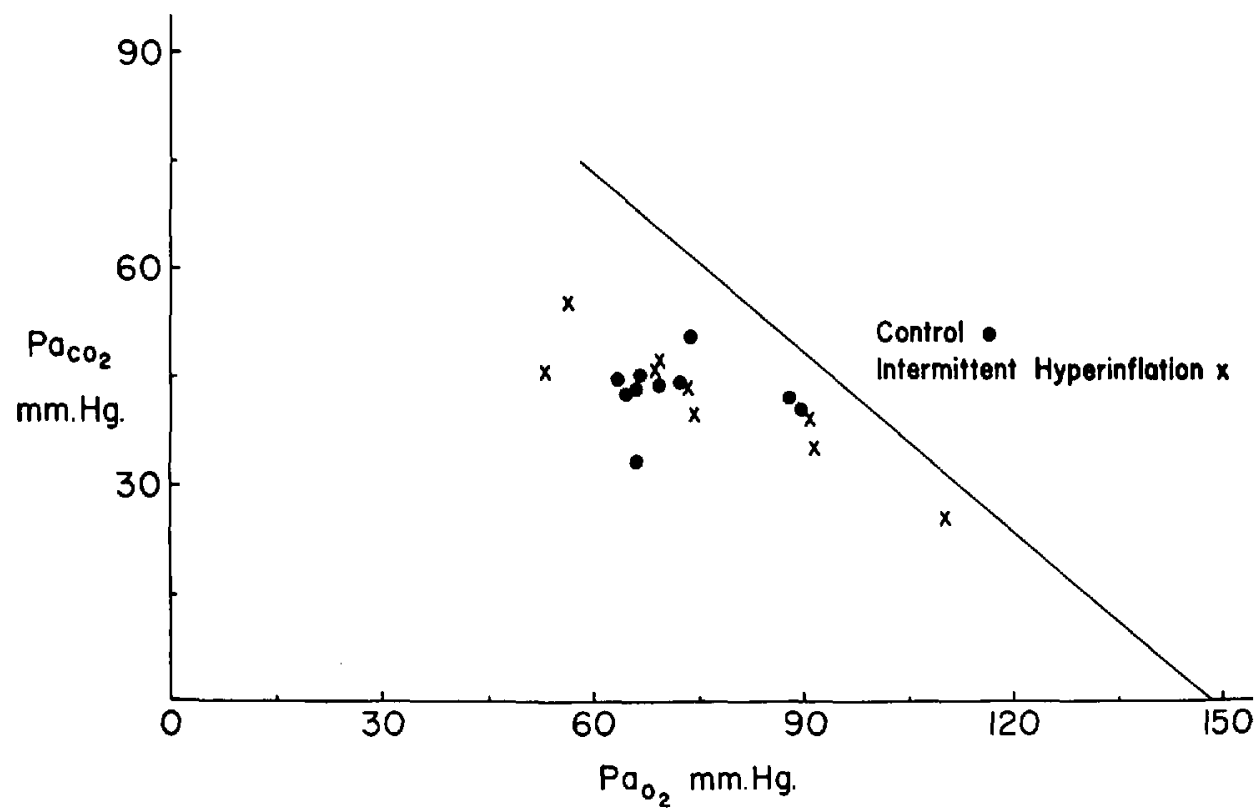

Ficure 2. Study Number I, 60 minutes postoperatively.

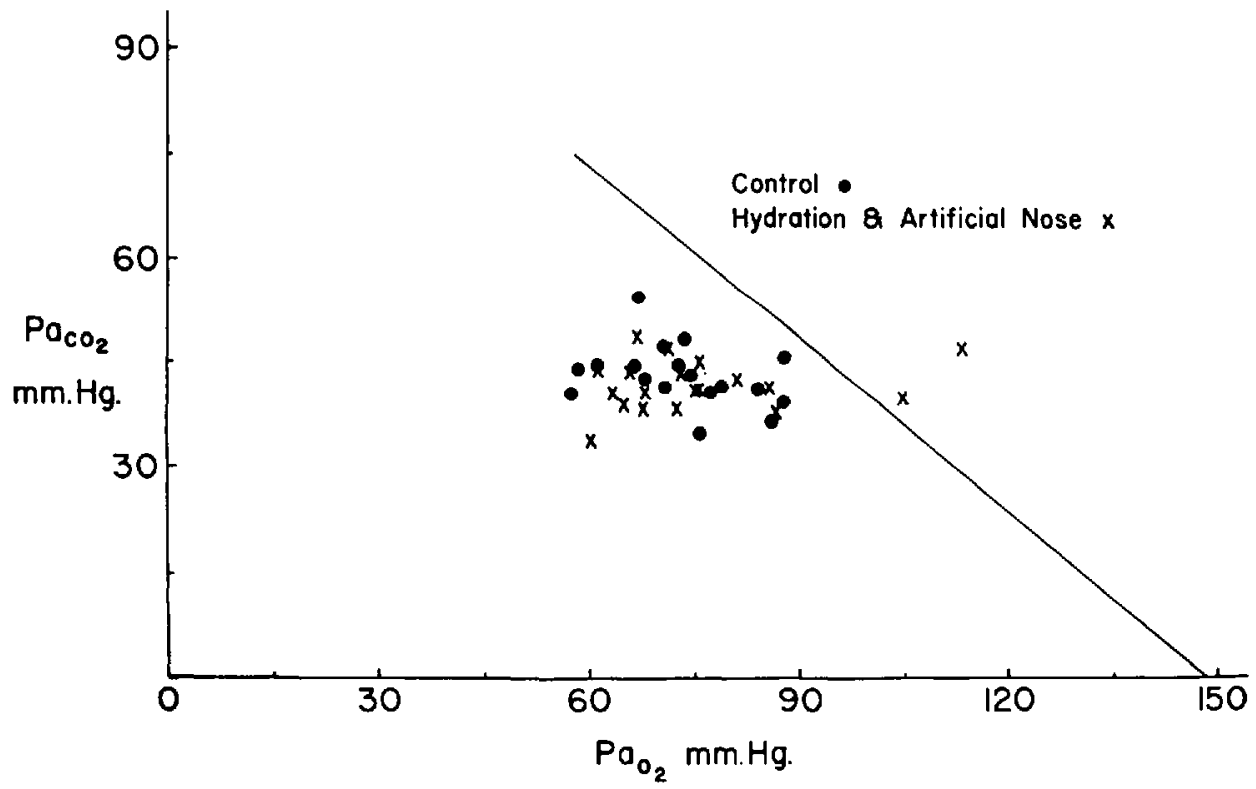

Figure 3. Study Number 2, spontaneously breathing patients 15 minutes postoperatively. 


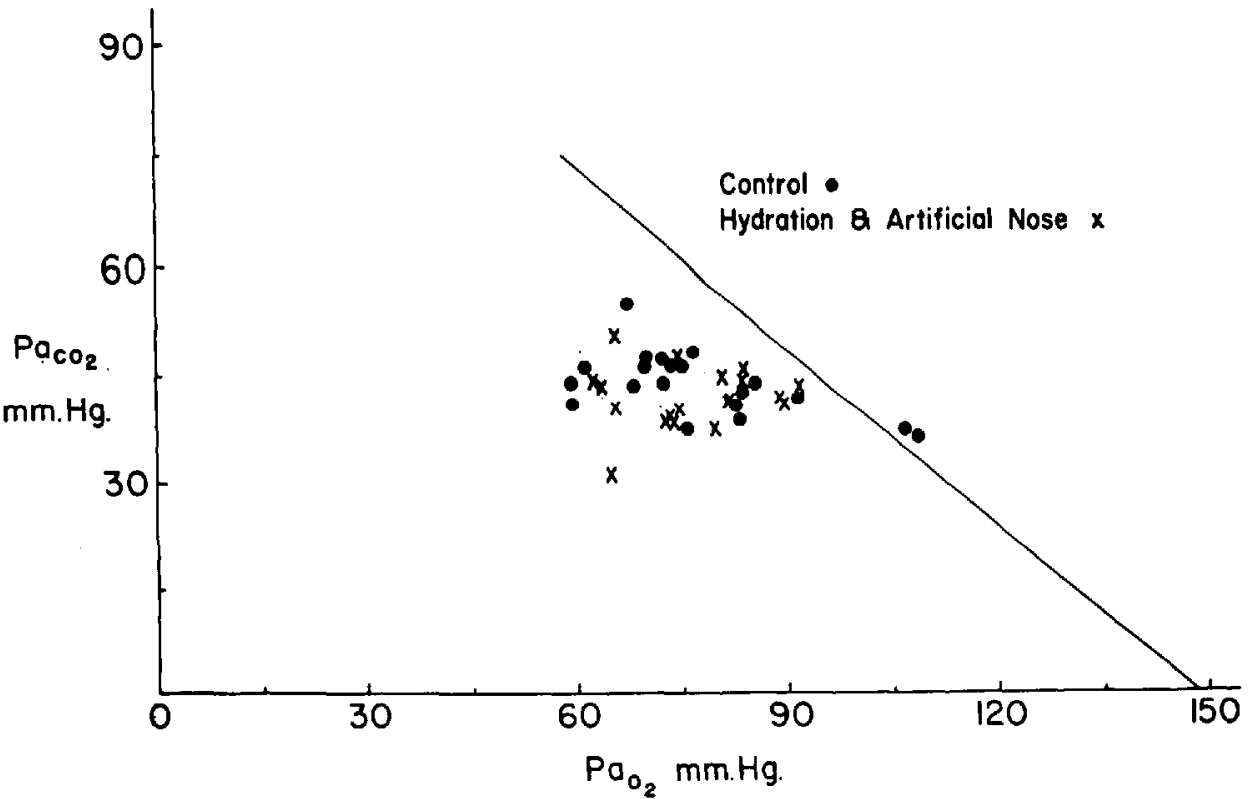

Figure 4. Study Number 2, spontaneously breathing patients 60 minutes postoperatively.

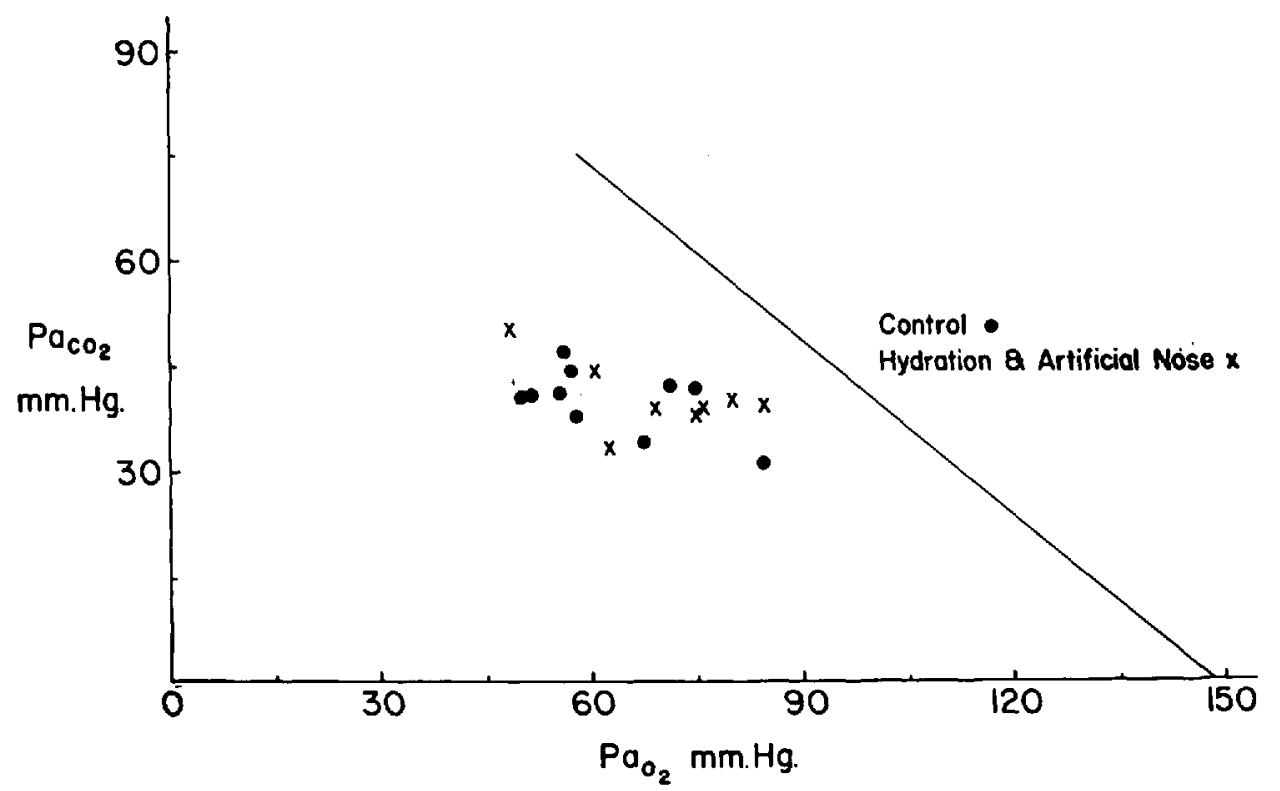

Figure 5. Study Number 2, artificially ventilated patients 15 minutes postoperatively. 


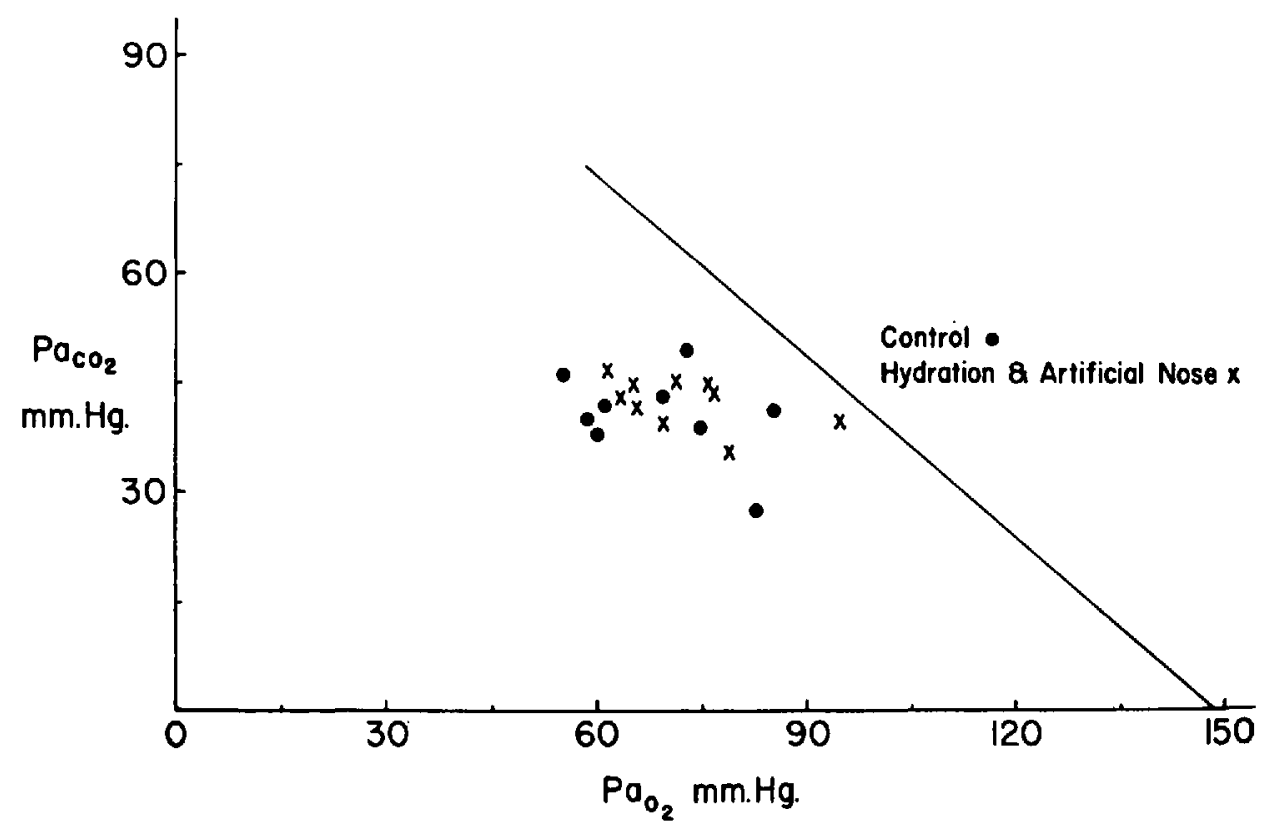

Figure 6. Study Number 2, artificially ventilated patients 60 minutes postoperatively.

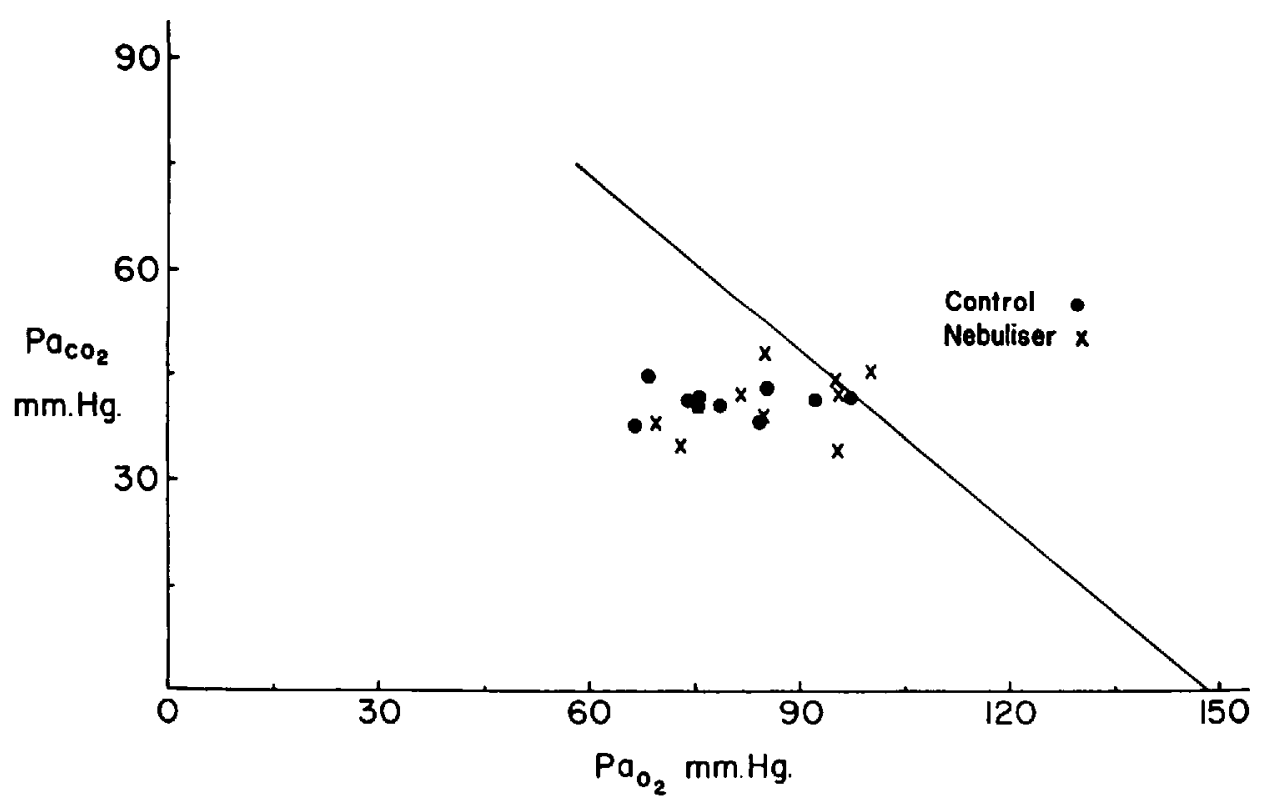

Figure 7. Study Number 3, preoperative values for all patients. 


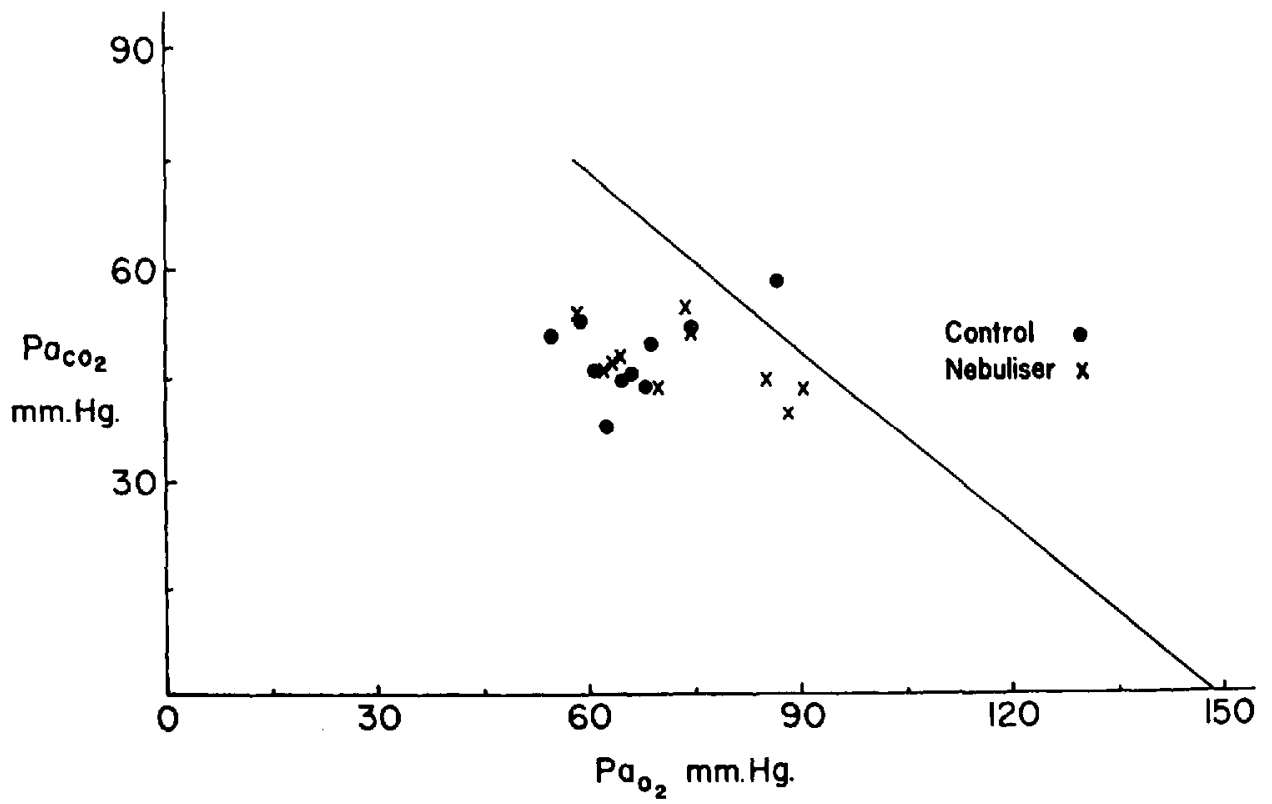

Figure 8. Study Number 3, 15 minutes postoperatively.

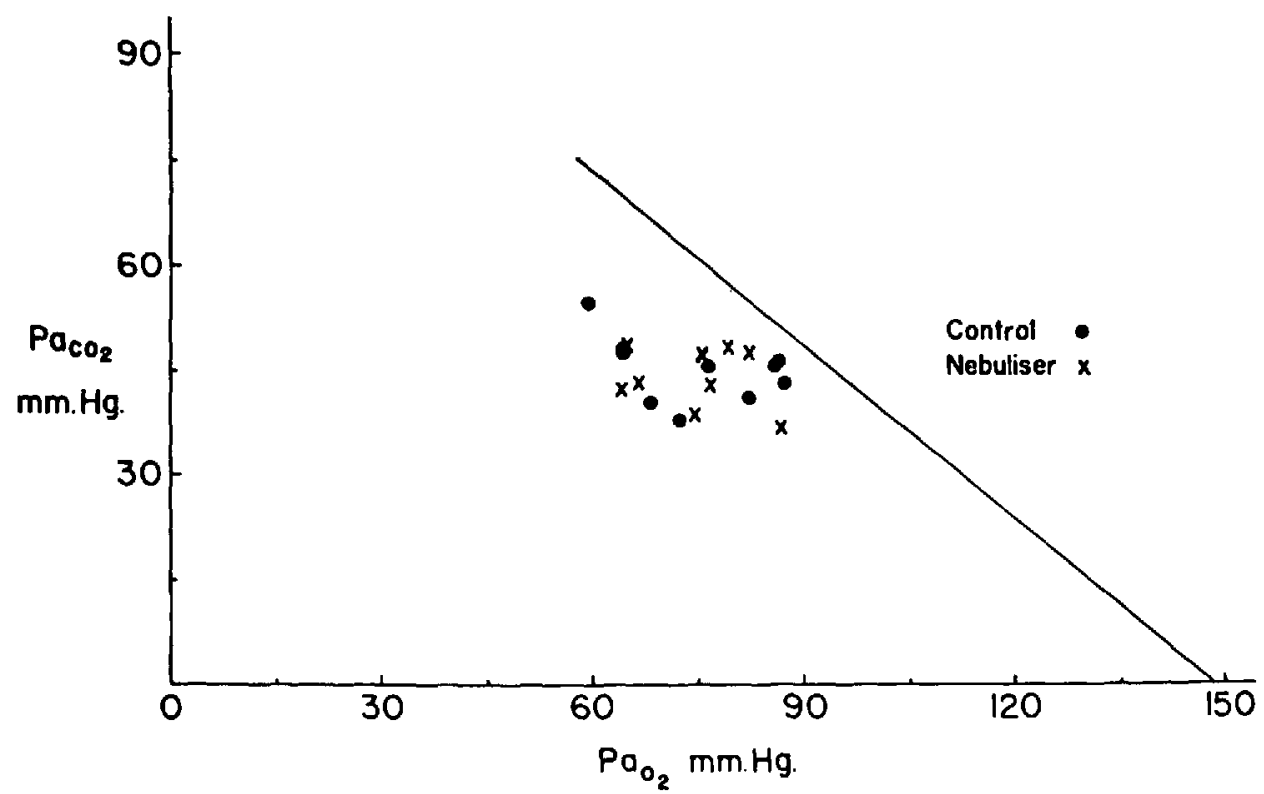

Figure 9. Study Number 3, 60 minutes postoperatively. 


\section{DisCUSSION}

The preoperative and postoperative control values obtained in these studies for arterial oxygen tension correspond to those reported in other series. ${ }^{1-3,8}$

Intermittent hyperinflation of the lungs, carried out during anaesthesia, was not effective in improving arterial oxygen tension postoperatively and the reason for this is not explained. Certainly, the patients in this study were relatively hypoxaemic postoperatively. One or more of three possible explanations may exist-the postoperative hypoxaemia may have been caused by factors other than loss of the intermittent sigh of normal conscious respiration, ${ }^{10}$ the degree of inflation may have been inadequate or ineffective, ${ }^{11}$ or the period of efficacy of each hyperinflation may be very short. This study did not include patients who might be particularly exposed to patchy atelectasis, such as those undergoing thoracotomy. However, the postoperative hypoxaemia associated with the more common types of surgery was not prevented by a manoeuvre designed to replace the normal intermittent sigh.

A drying of secretions by inspired gases may contribute to a diffuse atelectatic process, particularly when delivered through an endotracheal tube to a partially dehydrated patient, and this possibility is not disproved by the study. However, moderately vigorous measures designed to offset this problem failed to modify the degree of postoperative hypoxaemia in Studies 2 and 3.

Three other relationships have been coincidentally examined in the present studies. The importance of age in relation to arterial oxygen tension ${ }^{9,12}$ has been confirmed. Duration of operation has been shown not to be a significant factor $(r=-0.1)$, although no procedures lasted less than 30 minutes. $^{3}$ In the past, the importance of the interrelationship between arterial carbon dioxide and oxygen tensions has frequently been stressed. This relationship is complex. Thus, alveolar hypoventilation results in a fall in alveolar oxygen associated with a rise in alveolar carbon dioxide tensions. However, hypoxaemia produced by other means may stimulate alveolar hyperventilation, and a fall in arterial carbon dioxide tension may result. Any change in the latter will influence the oxyhaemoglobin dissociation curve and hence arterial oxygen tension, and the alveolar-arterial oxygen gradient. Finally, very low $R$ values in the unsteady state following controlled hyperventilation may produce arterial hypoxaemia. ${ }^{13}$ Thus, the actual arterial oxygen tension is the resultant of very many influences, and a correlation coefficient can only display the over-all situation. In these studies, there was a constant tendency for low oxygen and high carbon dioxide tensions to be associated-significantly in two groups. The correlations are not strong and do not entitle one to conclude that hypoventilation produced hypoxaemia. However, it has been shown that, whatever the cause, the degree of hypoxaemia observed was insufficient to stimulate ventilation in the circumstances under study.

The other possible causes of postoperative hypoxaemia are reviewed elsewhere. ${ }^{4}$ However, in summary, it is probable that more than one aetiological factor is involved. The ineffectiveness of measures designed to combat certain of these causes, as demonstrated in the present studies, suggest that other more important factors are frequently present. Functional residual capacity has been 
shown to fall during anaesthesia, ${ }^{14}$ and there is good evidence that much of the shunt is of blood passing partially unventilated alveoli. ${ }^{15,16}$ In the event of a low cardiac output postoperatively, the magnitude of the calculated shunt will be greater, ${ }^{17,18}$ as will be the case if arterial carbon dioxide tension is low or if, in the unsteady state, abnormally low $R$ values exist. The actual cause of the fall in FRC and the associated atelectasis has not been demonstrated, but there is strong suggestive evidence that this may be related to central depression and immobilization.

\section{SUMMARY}

One hundred patients were randomized into control and "treatment" groups, in three separate studies, to determine whether hypoxaemia in the immediate postoperative period could be minimized by manoeuvres applied during anaesthesia-intermittent hyperinflation of the lungs, rehydration and the use of an "artificial nose," and the addition of nebulized water to the inspired air. None of the methods studied produced any significant reduction in postoperative hypoxaemia. The relationship of postoperative arterial oxygen tension to age, duration of operation, and arterial carbon dioxide tension was examined statistically.

\section{RÉSUMÉ}

On a fait trois études séparées, dans le but d'évaluer l'efficacité de manœuvres pratiquées durant l'anesthésie pour diminuer l'hypoxémie post-opératoire. L'inflation intermittente des poumons, la correction de l'insuffisance pré-opératoire de liquides et l'usage d'un "nez artificiel" de même que l'humidification des gaz inspirés à l'aide d'eau vaporisée ont tour à tour été évaluées. On a divisé les malades en deux groupes, soit les "traités" et les témoins; on les a numérotés et on a examiné le sang artériel 15 et 60 minutes après l'opération. On a comparé statistiquement les résultats obtenus auprès de chacun des deux groupes, et on n'a observé acune différence importante. Les tensions d'oxygène artériel postopératoire se sont montrées plus faibles chez les malades âgés, sans rapport avec la durée de l'opération, et elles avaient tendance à être plus élevées chez les malades à faible tension de $\mathrm{CO}_{2}$ artériel.

\section{REFERENCES}

1. Nuns, J. F. \& PAyne, J. P. Hypoxaemia after General Anaesthesia. Lancet, ii: 631 (1962).

2. Stephen, C. R. \& Talton, I. Immediate Postoperative Care, with Particular Reference to Blood-Gas Studies. Canad. Anaesth. Soc. J. 1I: 586 (1964).

3. Marshall, B. M. \& Millar, R. A. Some Factors Influencing Postoperative Hypoxaemia. Anaesthesia. 20: 408 (1965).

4. Sellery, G. R. A Review of the Causes of Postoperative Hypoxia. Canad. Anaesth. Soc. J. 15: 142 (1968).

5. Severinghaus, J. W. Oxyhaemoglobin Dissociation Curve Correction for Temperature and $\mathrm{pH}$ Variation in Human Blood. J. Appl. Physiol. 12: 485 (1958).

6. RADFORD, E. P. JR. Ventilation Standards for Use in Artificial Respiration. J. Appl. Physiol. 7: 451 (1955).

7. Toremalm, N. G. A Heat and Moisture Exchanger for Post-Tracheotomy Care. An Experimental Study. Acta oto-laryng. 52:461 (1960). 
8. Conway, C. M. Arterial Oxygen Tensions in Surgical Patients. In A Symposium on Oxygen Measurements in Blood and Tissues and Their Significance. London: Churchill (1966).

9. NunN, J. F. Influence of Age and Other Factors on Hypoxaemia in the Postoperative Period. Lancet. ii: 466 (1965).

10. Bendixen, H. H.; Hedley-Whyte, J.; \& Laver, M. B. Impaired Oxygenation in Surgical Patients during General Anaesthesia with Controlled Ventilation. A Concept of Atelectasis. New England J. Med. 269: 991 (1963).

11. NunN, J. F.; Bergman, N. A.; \& Coleman, A. J. Factors Influencing the Arterial Oxygen Tension during Anaesthesia with Controlled Ventilation. Brit. J. Anaesth. 37: 898 (1965).

12. RaINe, J. M. \& Bishop, J. M. A-a Difference in $\mathrm{O}_{2}$ Tension and Physiological Dead Space in Normal Man. J. Appl. Physiol, 18: 284 (1963).

13. Sullnan, S. F.; Patterson, R. W.; \& Papper, E. M. Post-hyperventilation Hypoxia. J. Appl. Physiol. 22: 431 (1967).

14. Mean, J. \& Coliter, C. Relation of Volume History of Lungs to Respiratory Mechanics in Anesthetized Dogs. J. Appl. Physiol. 14: 669 (1959).

15. Conway, C. M. \& Payne, J. P. Postoperative Hypoxaemia and Oxygen Therapy. Brit. Med. J. i: 844 (1963).

16. Georg, J;; Honnum, I.; \& Mellemganard, K. The Mechanism of Hypoxaemia after Laparotomy. Thorax. 22: 382 (1967).

17. FalrLex, H. B. The Effect of Hyperventilation on Arterial Oxygen Tension: A Theoretical Analysis. Canad. Anaesth. Soc. J. 14: 87 (1967).

18. Kelman, G. R.; Nunn, J. F.; Prys-Roberts, C.; \& Greendaum, R. The Influence of Cardiac Output on Arterial Oxygenation: A Theoretical Study. Brit. J. Anaesth. 39: 450 (1967). 